This PDF is a selection from an out-of-print volume from the National Bureau of Economic Research

Volume Title: Tax Policy and the Economy, Volume 15

Volume Author/Editor: James M. Poterba, editor

Volume Publisher: MIT Press

Volume ISBN: 0-262-66122-5

Volume URL: http://www.nber.org/books/pote01-1

Publication Date: January 2001

Chapter Title: The Changing Importance of Income and Payroll Taxes on U.S. Families

Chapter Author: Andrew Mitrusi, James M. Poterba

Chapter URL: http://www.nber.org/chapters/c10855

Chapter pages in book: (p. 95 - 120) 


\title{
THE CHANGING IMPORTANCE OF INCOME AND PAYROLL TAXES ON U.S. FAMILIES
}

\author{
Andrew Mitrusi \\ NBER
}

James Poterba

Massachusetts Institute of Technology and NBER

\section{EXECUTIVE SUMMARY}

Nearly two-thirds of U.S. families currently pay more in payroll taxes than they pay in federal personal income taxes. In the lower strata of the family income distribution, payroll taxes exceed income taxes for nearly 90 percent of all tax-paying families. This paper documents the relative magnitude of income and payroll tax burdens on families of different types. It considers the differential importance of these taxes for married couples, single individuals, and single-parent families. The paper considers total tax payments as well as the marginal payroll and personal income tax rates facing families, and presents an exploratory analysis of how taking account of "tax benefit linkage" alters relative marginal payroll and income tax rates. The percentage of families for whom the marginal payroll

We are grateful to Inna Shapiro and especially to Daniel Feenberg for assistance in developing the TAXSIM program, and to Thomas Barthold, James Bickley, Len Burman, and David Weider for helpful comments. We thank the Smith Richardson Foundation, the National Science Foundation (Poterba), and the National Bureau of Economic Research for
research support. 
tax rate exceeds the marginal personal income tax rate falls from 54 percent to 9 percent when the effective payroll tax rate is measured net of the present discounted value of future social security benefits.

\section{INTRODUCTION}

Virtually all wage earners are liable for payroll taxes, but many individuals and families do not pay federal income taxes, even if they have labor income. The expansion of the Earned Income Tax Credit (EITC) and the increase in both the personal exemption and the personal deduction during the last two decades have removed many low- and modestincome families from the ranks of taxpayers and turned many of them into recipients of tax credits. As a result, payroll taxes now exceed federal personal income taxes for most U.S families.

This paper presents new evidence on the changing fraction of families who pay more in payroll taxes than in personal income taxes. It also explores the relationship between the marginal payroll tax rate and the marginal personal income tax rate. It begins by describing a recent expansion of the NBER TAXSIM program to include both payroll and income tax burdens. This expansion, which is described in detail in Mitrusi and Poterba (2000), combines information on tax filers from the Statistics of Income Master File with data on non-filers from the Current Population Survey. The expanded program generates estimates of the payroll tax and income tax burden on each family. This paper divides families into various population groups, such as married joint filers, single persons, and single-parent families, and compares the income and payroll tax burdens on families in different income strata in each of these groups.

While most of the paper focuses on the total income and payroll tax liability of different families, the last section considers the marginal tax rates associated with these two taxes. It shows that the statutory payroll tax rate, combining both the employer and employee share of the tax, exceeds the statutory income tax rate for 54 percent of families with labor income. We also present exploratory results that consider how recognizing that higher earnings result in both higher payroll taxes and potentially higher future social security benefits changes the estimated marginal tax rates. If the present discounted value of incremental future social security benefits is subtracted from the current statutory payroll tax rate, the fraction of families for whom the payroll tax rate exceeds the income tax rate falls from 54 percent to 9 percent.

The rest of the paper is divided into five sections. Section 2 provides a brief description of the data file and the tax calculation program that we use to estimate the distribution of tax burdens in various years. Section 3 
presents our central findings on the relative burdens of income and payroll taxes. The analysis focuses on estimates for calendar year 1999, but it also includes summary information at five-year intervals throughout the 1979-1999 period. We report information on relative tax burdens for all families, as well as for three subgroups: married couples, single individuals, and single-parent families. Section 4 tracks changes in the combined burden of income and payroll taxes over the 1979-1999 period. It also briefly discusses the importance of the EITC in changing the fraction of families that face personal income taxes in excess of their payroll taxes. Section 5 presents evidence on the marginal payroll and income tax rates facing families in different income classes. It also introduces "tax benefit linkage" and discusses measurement of the payroll tax rate net of the future social security benefits that may be associated with these taxes. Finally, a brief conclusion discusses several directions for further work.

\section{PAYROLL TAX IMPUTATION AND THE NBER TAXSIM PROGRAM}

The NBER TAXSIM model is a computer program that calculates federal income tax and payroll tax liabilities for a representative sample of U.S. families. It analyzes data from the statistics of Income (SOI) Public Use File, a stratified random sample of U.S. taxpayers that oversamples highincome tax returns. This sample of tax returns is merged with data from the Current Population Survey to incorporate information on families that do not file income tax returns. Feenberg and Coutts (1993) describe the personal income tax sections of the TAXSIM model in some detail. Feenberg, Mitrusi, and Poterba (1997) expand the TAXSIM program to consider sales, payroll, and income taxes for a single year, 1991. Mitrusi and Poterba (2000) extend the program to include information on payroll taxes for the 1979-1999 period, and describe many of the assumptions and imputations that are needed for such analysis. Four data and modeling issues which are discussed in that paper should be summarized briefly before considering the results.

First, the universe of tax returns from the SOI Public Use File must be augmented with a sample of families drawn from the Current Population Survey. This provides coverage of income tax non-filers, who may have payroll tax liability even though they do not appear in the personal income tax files. Potential non-filers are identified using a variant of the algorithm used by the Census Bureau to make CPS non-filer imputations. This algorithm relies on reported wage income and capital income to impute filer status. 
Second, earnings of married joint filers are allocated between the two spouses using data from the Survey of Consumer Finances (SCF). Unlike the SOI file, the SCF includes information on the earned income of each member of married-couple families. We use these data to impute the division of total earned income from tax returns for married-joint-filer families at different points in the income distribution. This allocation makes it possible to compute payroll tax liability for married couples.

Third, to estimate the utilization of education tax credits (particularly the HOPE credit and the Lifetime Learning Credit, which were introduced under the provisions of the Taxpayer Relief Act of 1997), one needs demographic information about tax filers. The SOI file does not report any detail about family structure, other than the number of dependents. We impute information on demographic structure using data from the Current Population Survey, again stratifying families by income level and by total number of persons in the family.

Finally, to relate our analysis to the current tax code, we age the most recent publicly available individual income tax return file, the 1995 SOI data file, to 1999 . This aging process relies on changes in the aggregate amounts of various income flows to generate an estimate of the 1999 distribution of family income, based on the actual distribution in 1995. Aging tax returns can introduce some errors, particularly when some income flows, such as capital gains realizations, move in a volatile fashion. Various approaches to aging tax returns are possible. For example, while we use information on several disaggregate measures of income to project 1999 incomes from the 1995 tax-return data, Ellwood and Liebman (2001) use the growth rate of personal income to age all components of family income. Our approach also differs from theirs in expanding the number of tax returns between 1995 and 1999.

In studying the federal income tax and the payroll tax, we usually combine the employer and the employee share of the payroll tax. We assume that workers ultimately bear the employer share of the payroll tax in the form of lower wages. We present some results, however, that separate the two components of the payroll tax.

Our analysis centers on calendar years as the basic unit of time, and on families, including single-person families, as the basic unit of observation. We follow the tax code in defining "families." To avoid double counting, we exclude dependent tax filers from our sample. Most of the "families" in our data set are groups of individuals who are listed on a single tax return. This approach differs from the approach to defining families in, for example, the Current Population Survey (CPS). In the CPS, a family is "a group of two persons or more, one of whom is a householder, residing together and related by birth, marriage, or adop- 
tion." Our definition of a family, in contrast, is based on economic dependency or marriage. The CPS would classify two adult siblings living together as a single family, while we would probably classify them as two families. The CPS would not include a dependent college student at a live-away college as part of the family that included the student's parents, while our approach would.

Throughout our analysis, we stratify families according to an adjusted AGI measure. This is defined as adjusted gross income (AGI) as reported on tax returns, plus employer-paid social security and Medicare taxes, plus the portion of social security benefits that are excluded from AGI, plus tax-exempt bond interest, plus contributions to individual retirement accounts and Keoghs. Some other studies of the distribution of income or payroll tax burdens use even more expansive definitions of family income that include estimates of transfer payments and other resource flows. We restrict our analysis to an income measure that can be constructed from data on tax returns. For a discussion of alternative measures, see U.S. Congress, Joint Committee on Taxation (1993).

\section{THE RELATIVE BURDEN OF INCOME TAXES AND PAYROLL TAXES, 1979-1999}

This section summarizes our basic findings on average income and payroll tax burdens by income class in 1999, and on the trends over time in the relative burdens of income and payroll taxes. While the findings in Table 1 are similar to those in Mitrusi and Poterba (2000), some of the results differ as a result of minor improvements in the TAXSIM program since that paper was completed.

\subsection{Tax Patterns, 1999}

Table 1 presents our estimates of the distribution of income and payroll tax liabilities across families in calendar year 1999. The table has two panels, one corresponding to all families, the other corresponding to all families that paid either income or payroll taxes. The table shows both the mean personal income tax payment and the mean payroll tax payment, for families in different adjusted AGI categories. It also shows the fraction of families for whom the combined employer and employee share of the payroll tax is greater than the income tax, and the fraction for whom the employee share alone exceeds the personal income tax.

The results in Table 1 show that for families in income classes below $\$ 100,000$, the average combined employer and employee payroll tax 
TABLE 1

Relationship between Income and Payroll Taxes, by Family Adjusted AGI, 1999

\begin{tabular}{|c|c|c|c|c|c|}
\hline $\begin{array}{l}1999 \\
\text { family } \\
\text { adjusted } \\
\text { AGI } \\
(\$ 1000)\end{array}$ & $\begin{array}{l}\text { Families } \\
\text { (millions) }\end{array}$ & $\begin{array}{c}\text { Mean } \\
\text { personal } \\
\text { income tax } \\
\text { (dollars) }\end{array}$ & $\begin{array}{l}\text { Mean payroll } \\
\text { tax, employer } \\
\text { and employee } \\
\text { payments } \\
\text { (dollars) }\end{array}$ & $\begin{array}{c}\text { Percent of } \\
\text { families with } \\
\text { combined } \\
\text { payroll tax }> \\
\text { personal } \\
\text { income tax }\end{array}$ & $\begin{array}{l}\text { Percent of } \\
\text { families with } \\
\text { employee } \\
\text { payroll tax }> \\
\text { personal } \\
\text { income tax }\end{array}$ \\
\hline \multicolumn{6}{|c|}{ All Families } \\
\hline $\begin{array}{l}<10 \\
10-20 \\
20-30 \\
30-40 \\
40-50 \\
50-75 \\
75-100 \\
100-200 \\
200-500 \\
500-1000 \\
>1000 \\
\text { All }\end{array}$ & $\begin{array}{r}28.83 \\
23.65 \\
18.11 \\
13.26 \\
10.57 \\
18.92 \\
9.93 \\
9.30 \\
2.03 \\
0.36 \\
0.18 \\
135.15\end{array}$ & $\begin{array}{r}-262 \\
-239 \\
1,062 \\
2,519 \\
3,942 \\
6,248 \\
10,629 \\
20,755 \\
64,481 \\
182,264 \\
799,100 \\
841\end{array}$ & $\begin{array}{r}400 \\
1,475 \\
2,833 \\
4,199 \\
5,405 \\
7,170 \\
9,950 \\
12,570 \\
14,394 \\
17,873 \\
28,848 \\
603\end{array}$ & $\begin{array}{r}46.4 \\
71.6 \\
81.7 \\
85.7 \\
74.5 \\
66.3 \\
55.0 \\
16.2 \\
0.1 \\
0.0 \\
0.0 \\
62.1\end{array}$ & $\begin{array}{r}46.1 \\
58.3 \\
43.2 \\
34.9 \\
27.9 \\
19.1 \\
6.3 \\
1.5 \\
0.1 \\
0.0 \\
0.0 \\
34.6\end{array}$ \\
\hline \multicolumn{6}{|c|}{ All Families with Tax Liability } \\
\hline $\begin{array}{l}<10 \\
10-20 \\
20-30 \\
30-40 \\
40-50 \\
50-75 \\
75-100 \\
100-200 \\
200-500 \\
500-1000 \\
>1000 \\
\text { All }\end{array}$ & $\begin{array}{r}13.70 \\
19.16 \\
17.25 \\
13.05 \\
10.52 \\
18.85 \\
9.92 \\
9.29 \\
2.03 \\
0.36 \\
0.18 \\
114.31\end{array}$ & $\begin{array}{r}-551 \\
-285 \\
1,118 \\
2,562 \\
3,962 \\
6,272 \\
10,636 \\
20,775 \\
64,503 \\
182,345 \\
798,446 \\
7,350\end{array}$ & $\begin{array}{r}842 \\
1,821 \\
2,975 \\
4,267 \\
5,432 \\
7,197 \\
9,957 \\
12,583 \\
14,399 \\
17,880 \\
28,853 \\
5,270\end{array}$ & $\begin{array}{r}97.6 \\
87.9 \\
85.5 \\
86.9 \\
74.9 \\
66.5 \\
55.1 \\
16.2 \\
0.1 \\
0.0 \\
0.0 \\
73.2\end{array}$ & $\begin{array}{r}97.5 \\
71.4 \\
45.1 \\
35.2 \\
28.0 \\
19.2 \\
6.3 \\
1.5 \\
0.1 \\
0.0 \\
0.0 \\
40.8\end{array}$ \\
\hline
\end{tabular}

Notes: Aggregate income and payroll taxes are $\$ 840$ billion and $\$ 602.9$ billion, respectively. In aggregate, 23.7 percent of families have personal income tax liabilities in excess of their payroll taxes, 62.1 percent have payroll taxes in excess of personal income taxes, and 14.3 percent have equal liabilities (usually zero). 
burden exceeds the average personal income tax burden. The disparities are particularly clear at lower income levels. For families with adjusted AGI between $\$ 20,000$ and $\$ 30,000$, for example, mean payroll taxes are roughly three times as great as mean income taxes. For families in lower adjusted AGI categories, mean federal income taxes are negative. This reflects the refundable portion of the EITC generating negative income tax payments. The average federal income tax burden does not approximate the average payroll tax burden until the $\$ 75,000-100,000$ adjusted AGI category. At higher adjusted AGI levels, income tax payments are substantially larger than payroll tax payments. This reflects both the capped base for the OASDI portion of the payroll tax, and the low rate for the hospital insurance portion relative to income tax rates. Payroll taxes exceed income taxes for 62 percent of all families, and for 73 percent of those with either income or payroll tax liability.

At very low income levels, there are a substantial number of families with no income or payroll tax liability. Nearly half of families with adjusted AGI of less than $\$ 10,000$ have neither payroll nor income tax liabilities. These families are not classified as having payroll taxes greater than income taxes, or vice versa. Payroll taxes exceed income taxes for 97.6 percent of the families in this income range with some tax liability.

The lower panel of Table 1 presents information on only those families who paid positive income or payroll tax in each year. While restricting the sample to this group hardly affects the results for families with income of more than $\$ 40,000$, it has substantial effects at lower income levels. For families with 1999 adjusted AGI between $\$ 10,000$ and $\$ 20,000$, for example, 71.6 percent of all families but 87.9 percent of families who paid some taxes had 1999 payroll taxes in excess of personal income taxes. In general, the share of tax-paying families with payroll taxes greater than income taxes is larger than the analogous share of all families.

The last column in both panels of Table 1 shows the fraction of families for whom the employee share of the payroll tax exceeds then personal income tax. Not surprisingly, excluding half of each family's payroll tax burden substantially reduces the likelihood that payroll taxes exceed personal income taxes. However, employee payroll taxes still exceed personal income taxes for 35 percent of all families, and for more than 40 percent of all families that pay taxes. Families in the lowest income ranges, with adjusted annual AGI of less than $\$ 20,000$, have a greater than 50-percent chance of paying more in employee payroll taxes than in personal income taxes. Conditional on paying any taxes at all, these families' chances of paying more in employee payroll taxes than in personal income taxes are greater than four in five. 
The results on income versus payroll taxes in Table 1 are broadly consistent with findings reported by the Congressional Budget Office (CBO) (1998). For example, CBO (1998) reports that at family income between $\$ 40,000$ and $\$ 50,000,78$ percent of families pay combined employer and employee payroll taxes that exceed their income tax. Our estimates in Table 1 are between 74 and 75 percent, depending on whether we exclude families that pay no taxes. The agreement between our estimates and those in CBO (1998) is greatest at middle income ranges. There are non-trivial disparities at both high and low incomes. For example, we estimate that 84 percent of families with incomes between $\$ 100,000$ and $\$ 200,000$ face income taxes greater than their payroll taxes. The CBO (1998) estimate is 66 percent.

The fact that we use a less expansive income definition than $\mathrm{CBO}$ may account for some of the differences between our findings and those in CBO (1998). We do not impute any information such as transfer payments that is not reported on tax returns. In addition, our approach to identifying non-filer families may differ from that used at $\mathrm{CBO}$. We follow an income tax definition of families, while the CBO uses a definition that is based on that in the Current Population Survey. Finally, we do not precisely match CBO's assumptions in aging returns from earlier years to 1999. Although we have not compared our findings with output from other models, for example the ITEP model described by Ettlinger and O'Hare (1998), we suspect that differences are likely to arise from similar issues.

The upper and lower panels of Table 1 highlight the importance of distinguishing families that pay taxes from other families when comparing the relative burdens of income and payroll taxes. Table 2 provides further insight on the distribution of families with and without tax liabilities across income classes. The table shows that of 135.2 million families in 1999, 114.3 million paid some taxes. This number exceeds the number of families with earnings (104.8 million). Table 2 shows that virtually all of the families with no income or payroll tax liability have adjusted AGI of less than $\$ 20,000$. By comparison, only about twothirds of families with no earnings are in this income range.

Table 3 presents further detail on the families with no tax payments, or no earnings, in 1999. The table disaggregates these two groups by family type. Roughly three-quarters of the families with no tax liability are single persons, while 18 percent are married couples. Nearly 80 percent of single persons without tax liability have adjusted AGI of less than $\$ 10,000$, while only 38 percent of non-taxpaying married couples are in this income range. More than one non-taxpaying married family in five has adjusted AGI of more than $\$ 20,000$. 


\section{TABLE 2}

Income Distribution of Families With and Without Tax Liability and Earnings, 1999

\begin{tabular}{lrcrrr} 
& \multicolumn{5}{c}{ Number (millions) } \\
\cline { 2 - 6 } $\begin{array}{l}\text { 1999 family } \\
\text { adjusted AGI }\end{array}$ & $\begin{array}{c}\text { All } \\
\text { familien) }\end{array}$ & $\begin{array}{c}\text { Families with } \\
\text { some tax } \\
\text { liability }\end{array}$ & $\begin{array}{c}\text { Families with } \\
\text { no tax } \\
\text { liability }\end{array}$ & $\begin{array}{c}\text { Families } \\
\text { with } \\
\text { earnings }\end{array}$ & $\begin{array}{c}\text { Families } \\
\text { with no } \\
\text { earnings }\end{array}$ \\
\hline$<10$ & 28.83 & 13.70 & 15.13 & 13.39 & 15.44 \\
$10-20$ & 23.65 & 19.16 & 4.49 & 17.17 & 6.48 \\
$20-30$ & 18.11 & 17.25 & 0.86 & 15.38 & 2.73 \\
$30-40$ & 13.26 & 13.05 & 0.21 & 12.03 & 1.23 \\
$40-50$ & 10.57 & 10.52 & 0.05 & 9.63 & 0.94 \\
$50-75$ & 18.92 & 18.85 & 0.07 & 17.12 & 1.80 \\
$75-100$ & 9.93 & 9.92 & 0.01 & 9.20 & 0.73 \\
$100-200$ & 9.30 & $9: 29$ & 0.01 & 8.60 & 0.70 \\
$200-500$ & 2.03 & 2.03 & 0.00 & 1.79 & 0.24 \\
$500-1000$ & 0.36 & 0.36 & 0.00 & 0.31 & 0.05 \\
$>1000$ & 0.18 & 0.18 & 0.00 & 0.15 & 0.03 \\
All & 135.15 & 114.31 & 20.84 & 104.79 & 30.36 \\
\hline
\end{tabular}

Source: Author's tabulations from 1995 SOI Public Use datafile, augnented with information from the Current Population Survey.

\subsection{Income Taxes vs. Payroll Taxes: The 1979-1999 Period}

Table 4 presents a longer-term perspective than Table 1 on the relative magnitude of payroll and income tax liabilities. [Like Table 1, this table closely resembles one in Mitrusi and Poterba (2000)]. Table 4 shows the results of applying income and payroll tax rules from five years1979, 1984, 1989, 1994, and 1999 - to the set of families whose 1999 income and payroll taxes were analyzed in Table 1. Recall that the 1999 family income distribution was constructed by aging families from the 1995 SOI Public Use File, augmented with families from the 1995 Current Population Survey, to 1999. When we apply the tax laws from other years to this set of families, we re-define the income thresholds in each year's tax laws to correspond to 1999 price levels. We make these adjustments using price changes as reflected in the Consumer Price Index.

To illustrate this procedure, consider our calculations for 1979. The Consumer Price Index for 1999 was 2.29 times the value for 1979 . We therefore multiply all of the nominal magnitudes in the income and payroll tax schedules for 1979 by 2.29 . We then apply the resulting tax code to our data set on the incomes of 1999 families. This calculation indicates what tax liabilities would have been in 1999 if the bracket 
TABLE 3

Income Distribution of Families with No Tax Liabilities or No

Earnings, 1999

\begin{tabular}{|c|c|c|c|c|}
\hline $\begin{array}{l}\text { Family AGI category } \\
(\$ 1000)\end{array}$ & All & $\begin{array}{l}\text { Single } \\
\text { persons }\end{array}$ & $\begin{array}{l}\text { Married- } \\
\text { couple } \\
\text { families }\end{array}$ & $\begin{array}{l}\text { Single- } \\
\text { parent } \\
\text { families }\end{array}$ \\
\hline \multicolumn{5}{|c|}{ Families with No Tax Liability } \\
\hline$<10$ & $72.6 \%$ & $78.3 \%$ & $37.7 \%$ & $92.2 \%$ \\
\hline $10-20$ & $21.6 \%$ & $19.6 \%$ & $39.7 \%$ & $5.9 \%$ \\
\hline $20-30$ & $4.1 \%$ & $1.3 \%$ & $17.0 \%$ & $1.5 \%$ \\
\hline $30-40$ & $1.0 \%$ & $0.3 \%$ & $4.2 \%$ & $0.4 \%$ \\
\hline $40-50$ & $0.2 \%$ & $0.2 \%$ & $0.8 \%$ & $0.0 \%$ \\
\hline $50-75$ & $0.3 \%$ & $0.4 \%$ & $0.4 \%$ & $0.0 \%$ \\
\hline $75-100$ & $0.0 \%$ & $0.0 \%$ & $0.1 \%$ & $0.0 \%$ \\
\hline $100-200$ & $0.0 \%$ & $0.0 \%$ & $0.1 \%$ & $0.0 \%$ \\
\hline $200-500$ & $0.0 \%$ & $0.0 \%$ & $0.0 \%$ & $0.0 \%$ \\
\hline $500-1000$ & $0.0 \%$ & $0.0 \%$ & $0.0 \%$ & $0.0 \%$ \\
\hline$>1000$ & $0.0 \%$ & $0.0 \%$ & $0.0 \%$ & $0.0 \%$ \\
\hline All & $100.0 \%$ & $100.0 \%$ & $100.0 \%$ & $100.0 \%$ \\
\hline $\begin{array}{l}\text { Number of families } \\
\text { (millions) }\end{array}$ & 20.84 & 14.56 & 3.78 & 2.51 \\
\hline \multicolumn{5}{|c|}{ Families with No Earnings } \\
\hline$<10$ & $50.8 \%$ & $59.2 \%$ & $18.0 \%$ & $87.2 \%$ \\
\hline $10-20$ & $21.3 \%$ & $21.9 \%$ & $24.8 \%$ & $6.3 \%$ \\
\hline $20-30$ & $9.0 \%$ & $6.8 \%$ & $16.7 \%$ & $2.1 \%$ \\
\hline $30-40$ & $4.0 \%$ & $3.1 \%$ & $7.4 \%$ & $1.2 \%$ \\
\hline $40-50$ & $3.1 \%$ & $2.5 \%$ & $5.6 \%$ & $0.3 \%$ \\
\hline $50-75$ & $5.9 \%$ & $3.6 \%$ & $13.4 \%$ & $1.2 \%$ \\
\hline 75-100 & $2.4 \%$ & $1.2 \%$ & $5.9 \%$ & $0.9 \%$ \\
\hline $100-200$ & $2.3 \%$ & $1.2 \%$ & $5.6 \%$ & $0.4 \%$ \\
\hline $200-500$ & $0.8 \%$ & $0.4 \%$ & $1.9 \%$ & $0.3 \%$ \\
\hline $500-1000$ & $0.2 \%$ & $0.1 \%$ & $0.4 \%$ & $0.1 \%$ \\
\hline$>1000$ & $0.1 \%$ & $0.0 \%$ & $0.2 \%$ & $0.0 \%$ \\
\hline & $100.0 \%$ & $100.0 \%$ & $100.0 \%$ & $100.0 \%$ \\
\hline $\begin{array}{l}\text { Number of families } \\
\text { (millions) }\end{array}$ & 30.36 & 19.74 & 7.96 & 2.65 \\
\hline
\end{tabular}

Source: Authors' tabulations using data from 1995 SOI Public Use File, augmented with information from Current Population Survey.

amounts in tax codes from earlier years had been indexed for inflation, but not for other changes in the economy.

Our calculation assumes that the U.S. economy would have evolved precisely as it did over the last twenty years if the tax code had not been changed since 1979, except for bracket indexation. Such an assumption 
TABLE 4

Proportion of Families with Payroll Tax Exceeding Personal Income Tax

\begin{tabular}{lrrrrr}
\hline \multirow{2}{*}{$\begin{array}{l}\text { 1999 Family Adjusted } \\
\text { AGI (\$1000) }\end{array}$} & \multicolumn{5}{c}{ Proportion (\%) } \\
\cline { 2 - 5 } & 1979 & 1984 & 1989 & 1994 & 1999 \\
\hline & \multicolumn{5}{c}{ All Families } \\
$<10$ & 46.4 & 46.3 & 46.4 & 46.4 & 46.4 \\
$10-20$ & 71.2 & 70.8 & 71.3 & 71.5 & 71.6 \\
$20-30$ & 66.7 & 78.8 & 81.1 & 81.5 & 81.7 \\
$30-40$ & 45.8 & 58.8 & 84.5 & 85.3 & 85.7 \\
$40-50$ & 37.5 & 48.0 & 68.9 & 73.5 & 74.5 \\
$50-75$ & 19.1 & 28.8 & 63.4 & 65.5 & 66.3 \\
$75-100$ & 4.6 & 7.3 & 41.3 & 49.1 & 55.0 \\
$100-200$ & 1.0 & 1.5 & 9.7 & 13.4 & 16.2 \\
$200-500$ & 0.4 & 0.4 & 0.1 & 0.1 & 0.1 \\
$500-1000$ & 0.2 & 0.3 & 0 & 0 & 0 \\
$>1000$ & 0.4 & 0.5 & 0 & 0 & 0 \\
All & 41.8 & 47.0 & 59.5 & 61.1 & 62.1
\end{tabular}

Families with Positive Personal Income Tax or Payroll Tax

\begin{tabular}{lrrrrr}
$<10$ & 97.7 & 97.4 & 97.6 & 97.6 & 97.6 \\
$10-20$ & 87.5 & 87.2 & 87.6 & 87.8 & 87.9 \\
$20-30$ & 70.0 & 82.7 & 85.0 & 85.4 & 85.5 \\
$30-40$ & 46.4 & 59.7 & 85.8 & 86.5 & 86.9 \\
$40-50$ & 37.7 & 48.2 & 69.2 & 73.8 & 74.9 \\
$50-75$ & 19.1 & 28.9 & 63.7 & 65.8 & 66.5 \\
$75-100$ & 4.6 & 7.3 & 41.3 & 49.2 & 55.1 \\
$100-200$ & 1.0 & 1.5 & 9.7 & 13.5 & 16.2 \\
$200-500$ & 0.4 & 0.4 & 0.1 & 0.1 & 0.1 \\
$500-1000$ & 0.2 & 0.3 & 0 & 0 & 0 \\
$>1000$ & 0.4 & 0.5 & 0 & 0 & 0 \\
All & 49.4 & 55.6 & 70.2 & 72.2 & 73.2 \\
\hline
\end{tabular}

Source: Authors' calculations using TAXSIM and payroll tax simulation programs for the 1979-1999 period. Families are grouped according to their 1999 adjusted AGI. Income values in the tax laws for other years are aged to 1999 using changes in the Consumer Price Index.

is open to substantial question, and recent research, including Felstein (1995), Gruber and Saez (2000), and other studies surveyed in the latter study, suggests that there may be important links between the distribution of marginal tax rates and reported family income.

The appeal of our assumption that only nominal magnitudes in the tax code have changed is that it allows us to highlight the impact of changing tax rules on the tax payments of families at different points in the income distribution. Table 4 shows the percentage of families for whom 
the payroll tax would have exceeded the personal income tax if the tax laws from various years had applied in 1999. The upper panel of the table considers all families, while the lower panel focuses on the set of families with positive income or payroll tax liability in each year. Our discussion will focus primarily on the lower panel.

Table 4 shows that 49 percent of all tax-paying families in 1999 would have paid more in payroll taxes than in personal income taxes if the 1979 income tax and payroll tax schedules had remained in force, indexed for inflation. The actual 1999 statistic was 73 percent. The table shows that for families at the bottom of the income distribution, the probability of paying payroll taxes in excess of income taxes has remained relatively stable, at a very high value, over the last two decades. For families with slightly higher incomes, however, between $\$ 30,000$ and $\$ 75,000$ in 1999 , there has been a sharp increase in the likelihood that payroll tax payments exceed income tax payments. For a family with 1999 adjusted AGI between $\$ 40,000$ and $\$ 50,000$, for example, the probability that payroll taxes exceed income taxes has roughly doubled since 1979. Most of the increase took place between 1984 and 1989. Such families would have had a 38-percent chance of facing payroll taxes in excess of income taxes if the 1979 tax law had still been in effect, but they faced a 75-percent chance of payroll taxes exceeding income taxes under the 1999 law. There are similar changes in the probability of payroll taxes exceeding income taxes for families in other middle-income ranges.

Table 4 also shows that at higher income ranges, between $\$ 75,000$ and $\$ 100,000$ in 1999 , there has been a sharp increase in the likelihood that the payroll tax exceeds the income tax. This reflects both the removal of the income ceiling on the hospital-insurance payroll tax and changes in the personal income tax schedule that were enacted in the 1980s. The entries in Table 4 would be different if a year other than 1999 had been used as the benchmark year for constructing the family income distribution. Results in Mitrusi and Poterba (2000), however, suggest that using the 1979 family income distribution in place of the 1999 income distribution would not substantially affect the results.

\subsection{Income Taxes vs. Payroll Taxes: Differences by Family Type}

Table 4 presents data on income taxes and payroll taxes for all families, but it does not provide any disaggregation other than income range. Table 5 moves beyond this, and considers the percentage of tax-paying families stratified by family type for whom payroll taxes exceed income taxes. Table 5 follows our earlier discussion of non-taxpayers in distinguishing three groups of families: married joint filers, single individuals, 
TABLE 5

Proportion of Families with Positive Taxes for Whom Payroll Taxes Exceed Personal Income Tax, by Family Type, 1979-1999

\begin{tabular}{lrrrrr} 
1999 Family Adjusted & \multicolumn{5}{c}{ Proportion (\%) } \\
\cline { 2 - 5 } AGI (\$1000) & 1979 & 1984 & 1989 & 1994 & 1999 \\
\hline \multicolumn{5}{c}{ Married Couples } \\
$<10$ & 99.9 & 99.8 & 100.0 & 100.0 & 100.0 \\
$10-20$ & 85.7 & 83.2 & 85.3 & 85.5 & 85.5 \\
$20-30$ & 79.4 & 78.4 & 79.8 & 80.2 & 80.4 \\
$30-40$ & 81.6 & 82.3 & 84.1 & 84.5 & 84.9 \\
$40-50$ & 65.7 & 77.7 & 83.6 & 84.0 & 84.4 \\
$50-75$ & 25.6 & 37.8 & 79.4 & 80.4 & 80.4 \\
$75-100$ & 5.4 & 8.4 & 48.2 & 56.8 & 63.1 \\
$100-200$ & 1.1 & 1.6 & 11.0 & 15.3 & 18.4 \\
$200-500$ & 0.4 & 0.4 & 0.1 & 0.1 & 0.1 \\
$500-1000$ & 0.3 & 0.3 & 0.0 & 0.0 & 0.0 \\
$>1000$ & 0.4 & 0.5 & 0.0 & 0.0 & 0.0 \\
All & 38.5 & 43.0 & 62.2 & 64.7 & 66.3
\end{tabular}

Single Persons

$\begin{array}{lrrrrr}<10 & 96.3 & 95.9 & 96.1 & 96.2 & 96.2 \\ 10-20 & 82.2 & 82.8 & 82.7 & 82.9 & 83.0 \\ 20-30 & 53.6 & 79.0 & 82.4 & 82.7 & 82.8 \\ 30-40 & 9.4 & 31.3 & 82.9 & 84.1 & 84.7 \\ 40-50 & 6.5 & 14.0 & 43.6 & 54.4 & 56.1 \\ 50-75 & 2.8 & 5.7 & 17.1 & 20.5 & 21.2 \\ 75-100 & 1.0 & 1.7 & 3.0 & 5.1 & 6.7 \\ 100-200 & 0.4 & 0.5 & 0.2 & 0.3 & 0.6 \\ 200-500 & 0.9 & 0.7 & 0.2 & 0.2 & 0.2 \\ 500-1000 & 0.2 & 0.2 & 0.1 & 0.1 & 0.1 \\ >1000 & 0.5 & 0.6 & 0.1 & 0.0 & 0.0 \\ \text { All } & 49.8 & 58.8 & 70.4 & 72.1 & 72.5\end{array}$

Single-Parent Families

\begin{tabular}{lrrrrr}
$<10$ & 99.9 & 99.9 & 99.9 & 99.9 & 99.9 \\
$10-20$ & 99.7 & 99.1 & 99.5 & 99.5 & 99.6 \\
$20-30$ & 97.1 & 97.5 & 98.6 & 98.9 & 99.1 \\
$30-40$ & 71.6 & 88.7 & 97.6 & 97.6 & 97.9 \\
$40-50$ & 31.4 & 45.8 & 94.5 & 95.8 & 97.2 \\
$50-75$ & 12.6 & 22.8 & 69.4 & 76.8 & 84.7 \\
$75-100$ & 0.5 & 2.6 & 16.7 & 26.2 & 37.0 \\
$100-200$ & 0.1 & 0.1 & 0.6 & 0.9 & 1.1 \\
$200-500$ & 1.0 & 1.0 & 0.3 & 0.3 & 0.3 \\
$500-1000$ & 0.1 & 0.1 & 0.0 & 0.0 & 0.0 \\
$>1000$ & 0.5 & 1.6 & 0.0 & 0.0 & 0.0 \\
All & 79.6 & 83.6 & 92.9 & 93.9 & 95.0 \\
\hline
\end{tabular}

Source: Authors' calculations using TAXSIM and payroll tax simulation programs for the 1979-1999 period. Families are grouped according to their 1999 adjusted AGI. Income values in the tax laws for other years are aged to 1999 using changes in the Consumer Price Index. 
and single-parent families. There are differences in the relative importance of income and payroll taxes across these groups.

The first panel of Table 5 focuses on married joint filers. The results for this group are broadly similar to those for the entire family population in Table 4. There is little change during the 1979-1999 period in the fraction of low-income married joint filers for whom the payroll tax exceeds the income tax. This fraction is high throughout the period. There is a sharp increase in the fraction of middle- and upper-middle-income families facing payroll taxes in excess of income taxes, with most of the increase taking place in the mid-1980s. For married joint filers with adjusted AGI between $\$ 75,000$ and $\$ 100,000$, for example, the probability that payroll taxes exceed income taxes rose from 5.4 percent in 1979 , to 48.2 percent in 1989 , to 63.1 percent in 1999.

The second and third panels of Table 5 present comparable information for single individuals and for single-parent families. There are some differences between the time-series patterns that emerge in these two panels of Table 5 and the profiles for all families in Table 4. There are also clear differences between married couples, single individuals, and singleparent families. At the lowest income levels, there is a very high probability that payroll taxes exceed personal income taxes for families in all three groups. The likelihood that payroll taxes exceed personal income taxes is much greater, however, for middle- and upper-middle-income marriedcouple families, and for families with a single parent, than for single individuals. There are also differences at higher income levels. At adjusted AGI levels between $\$ 100,000$ and $\$ 200,000$, for example, only 1.1 percent of single-parent families and 0.6 percent of single persons face payroll taxes in excess of personal income taxes, while 18.4 percent of married couples face higher payroll taxes.

This difference between married couples and other families reflects two factors. First, married couples at a given income level can have two earners, while families in the other categories have only a single earner. Payroll taxes can be higher, as a result of the cap on taxable earnings, when there are two earners rather than one for a given level of family earnings. Second, the income tax rate structure for married joint filers is more generous than that for single individuals and heads of household.

The results in Table 5 suggest differences in the relative importance of payroll and individual income taxes for families of different types. These differences are due to systematic differences in wage and other income across groups, as well as to the structure of the tax system. The findings in Table 5 also suggest differences in the patterns over time in the relative importance of income and payroll taxes. For married-couple families, in particular, the payroll tax has become increasingly important in the last 
two decades. While the share of married-couple families for whom the payroll tax exceeds personal income tax liabilities was 66.3 percent in 1999, it would have been 38.5 percent if the 1979 tax code, indexed for inflation, had still been in force. By comparison, for single-parent families the corresponding values are 95 percent (1999 law) and 79.6 percent (1979 law). For single individuals, the experience is closer to that for married couples, with the fraction facing higher payroll taxes rising from 49.8 percent (1979 law) to 72.5 percent (1999 law). For all three groups of families, the most dramatic increases in the probability that the payroll tax exceeds the personal income tax take place at middle income ranges. The most affected income range is somewhat higher for married-couple families than for either single individuals or single-parent families.

\section{COMPARING THE LEVEL OF INCOME AND PAYROLL TAX LIABILITIES, 1979-1999}

Tables 4 and 5 show the percentage of families for whom the combined employer and employee payroll tax exceeds the federal personal income tax, but they do not describe the overall level of income and payroll tax burdens. Table 6 addresses this issue. It shows the level of the payroll and income tax burden, for families in different adjusted AGI categories, for the period 1979-1999. The upper panel of the table provides information for all families, while the lower panel focuses on families with positive income or payroll tax liability.

Table 6 shows that for families with 1999 adjusted AGI below $\$ 10,000$, total tax liabilities, income plus payroll taxes, were one third lower in 1999 than they would have been if the 1979 tax code had remained in force. For such families, average tax burdens rose from $\$ 224$ to $\$ 308$ (measured in 1999 dollars) between 1979 and 1984, and then declined to $\$ 138$ by 1999 . This emphasizes the importance of the tax changes in the mid-1980s in affecting the distribution of tax burdens at lower income levels. For families in a broad income range above $\$ 10,000$, and with incomes as high as $\$ 200,000$, the average combined burden of the income and payroll tax was quite similar in 1999 to what it would have been if the 1979 tax law had remained in force, indexed only for inflation. For the small set of families with adjusted AGI in excess of $\$ 200,000$, the table shows a decline in tax burdens between 1979 and 1999. The year with the lowest tax burden for these families is 1989, when the Tax Reform Act of 1986 had been fully phased in and before either the 1990 or 1993 increases in the marginal tax rates on highestincome taxpayers took effect. 
TABLE 6

Average Family Personal Income and Payroll Tax, 1979-1999

\begin{tabular}{llllll}
\hline 1999 family adjusted & \multicolumn{5}{c}{ Average tax burden $(\$)$} \\
\cline { 2 - 6 } AGI $(\$ 1000)$ & 1979 & 1984 & 1989 & 1994 & 1999 \\
\hline
\end{tabular}

\begin{tabular}{lrrrrr}
\multicolumn{5}{c}{ All Families } \\
$<10$ & 224 & 308 & 289 & 195 & 138 \\
$10-20$ & 1,369 & 1,903 & 1,637 & 1,379 & 1,236 \\
$20-30$ & 3,925 & 4,487 & 4,222 & 4,126 & 3,897 \\
$30-40$ & 6,657 & 7,299 & 6,886 & 6,940 & 6,719 \\
$40-50$ & 9,289 & 10,064 & 9,518 & 9,582 & 9,349 \\
$50-75$ & 13,302 & 14,603 & 13,474 & 13,656 & 13,418 \\
$75-100$ & 20,064 & 22,185 & 20,216 & 20,790 & 20,578 \\
$100-200$ & 34,293 & 36,586 & 32,241 & 33,517 & 33,325 \\
$200-500$ & 90,741 & 88,109 & 72,243 & 80,862 & 78,875 \\
$500-1000$ & 251,856 & 228,635 & 166,463 & 209,813 & 200,137 \\
$>1000$ & $1,118,154$ & 941,207 & 731,283 & 923,748 & 827,948 \\
All & 11,430 & 11,900 & 10,440 & 11,030 & 10,680
\end{tabular}

Families with Positive Income or Payroll Tax

\begin{tabular}{lrrrrr}
$<10$ & 472 & 645 & 608 & 410 & 291 \\
$10-20$ & 1,690 & 2,342 & 2,023 & 1,710 & 1,536 \\
$20-30$ & 4,119 & 4,707 & 4,432 & 4,333 & 4,095 \\
$30-40$ & 6,764 & 7,415 & 6,997 & 7,054 & 6,831 \\
$40-50$ & 9,334 & 10,113 & 9,565 & 9,629 & 9,395 \\
$50-75$ & 13,352 & 14,658 & 13,524 & 13,707 & 13,469 \\
$75-100$ & 20,077 & 22,199 & 20,230 & 20,804 & 20,592 \\
$100-200$ & 34,327 & 36,623 & 32,273 & 33,551 & 33,358 \\
$200-500$ & 90,771 & 88,138 & 72,268 & 80,890 & 78,902 \\
$500-1000$ & 251,965 & 228,736 & 166,537 & 209,906 & 200,225 \\
$>1000$ & $1,118,304$ & 941,358 & 731,401 & 923,897 & 828,082 \\
All & 13,510 & 14,060 & 12,340 & 13,040 & 12,620 \\
\hline
\end{tabular}

Source: Authors' calculations using TAXSIM and payroll tax simulation programs for the 1979-1999 period. Families are grouped according to their 1999 adjusted AGI. Income values in the tax laws for other years are aged to 1999 using changes in the Consumer Price Index.

Most of the changes in combined payroll and income taxes in Table 6 are due to changes in the income tax rather than the payroll tax. One income tax change during the period we study that is particularly significant is the expansion, in 1986 and in subsequent years, in the EITC (now the Earned Income Credit). Because the EITC is refundable, it has had the effect of creating negative income tax liabilities for a substantial group of taxpayers in recent years. 
The EITC was introduced in part to offset the rising payroll tax liabilities of low-income families with labor income, and to a substantial degree it has achieved this goal. Mitrusi and Poterba (2000) show that payroll taxes net of the EITC have declined for the average family with an adjusted AGI below $\$ 20,000$, while they have increased for families with incomes above this range. For all taxpaying families, the average payroll tax payment (net of the EITC) rose from $\$ 3640$ in 1979 to $\$ 5010$ in 1999. The average payment for families with income of less than $\$ 20,000$ declined, and the average for those with incomes between $\$ 20,000$ and $\$ 30,000$ rose by only $\$ 342$. At higher income levels, the increases in payroll taxes net of the EITC are more pronounced.

\section{MARGINAL TAX RATES AND TAX BENEFIT LINKAGES}

Our analysis so far has focused on the total amount that families pay in income and payroll taxes, rather than on the marginal tax rates that these families face as a result of these taxes. This section considers the distribution of marginal tax rates for each of these taxes, as well as the likelihood that the marginal payroll tax rate exceeds the marginal income tax rate.

Before discussing specific values for marginal tax rates, it is important to note that our inclusion of employer-paid payroll taxes, typically 7.65 percent of wages, in our income measure has implications for effective statutory income and payroll tax rates on wage income. Rather than the 15.3-percent statutory payroll tax rate that is usually discussed, the effective payroll tax rate is $0.153 /(1+0.0765)=0.142$, or 14.2 percent. Similarly, in this case a 28-percent personal income tax rate becomes 0.28 / $1.0765=0.260$. While we recognize that these are the operative marginal tax rates given our definition of income, we still present information using the conventional marginal tax rates, such as 15 and 28 percent for the personal income tax and 15.3 percent for the payroll tax. We do this primarily for ease of comprehension. Statutory tax rates are very familiar, while adjusted rates are not.

\subsection{Marginal Tax Rates}

There is relatively little variation in the marginal payroll tax rate that a family can face, since wage earners must pay either 15.3 percent, or 2.9 percent (if they earn more than the OASDI earnings cap), of their labor income in payroll taxes. We estimate that in 1999, 94.9 million families faced a marginal payroll tax rate of 15.3 percent on their labor income, 6.0 million faced a marginal tax rate of 2.9 percent, and 3.8 million faced an intermediate rate of 9.1 percent (employer plus employee rate). The 
9.1-percent rate arises when one member of a married couple has earnings above the OASDI earnings cap, while another has earnings below the cap. As Table 2 showed, we estimate that 104.8 million families had some type of labor income in 1999. We focus on this group of families, rather than the universe of 135.2 million families or the 114.3 million taxpaying families that we considered above, for the remainder of our analysis.

We calculate marginal payroll tax rates only on those who have labor earnings. Thus, the marginal payroll tax rate on a married couple, in which the wife earns more than the OASDI salary cap and the husband does not report any labor income, would be 2.9 percent. An alternative approach, which we do not pursue, would assign a 15.3 percent marginal tax rate to the non-earning spouse, on the principle that this would be the relevant marginal tax rate on the next dollar of earnings for this individual. Our calculation assumes that marginal changes in labor income result from changes in labor supply by those who are already working, rather than from changes in labor-force participation.

While there are few marginal payroll tax rates, there are many marginal income tax rates. The combination of credits, credit phaseouts, and other provisions generates a wide variety of potential tax rates. Table 7

\section{TABLE 7}

Distribution of Families with Wage Income by Marginal Personal Income Tax Rates, 1999

\begin{tabular}{lcc}
\hline $\begin{array}{l}\text { Marginal income } \\
\text { tax rate (\%) }\end{array}$ & $\begin{array}{c}\text { Number of families } \\
\text { (millions) }\end{array}$ & $\begin{array}{r}\text { Percentage } \\
\text { of families }\end{array}$ \\
\hline-40 & 1.99 & $1.90 \%$ \\
-34 & 1.57 & 1.50 \\
-33 to -1 & 0.14 & 0.13 \\
0 & 12.22 & 11.66 \\
1 to 14 & 0.61 & 0.58 \\
15 & 39.70 & 37.89 \\
16 to 27 & 11.95 & 11.40 \\
28 & 20.39 & 19.46 \\
29 to 30 & 4.07 & 3.88 \\
31 & 3.71 & 3.54 \\
32 to 35 & 4.36 & 4.16 \\
36 & 0.08 & 0.08 \\
37 to 39.5 & 2.79 & 2.66 \\
39.6 & 0.07 & 0.07 \\
$>39.6$ & 1.14 & 1.09 \\
Total & 104.79 & 100.00 \\
\hline
\end{tabular}

Notes: Authors' tabulations using the NBER TAXSIM model. See text for further details. 
shows the number of families facing tax rates in a number of different ranges. Roughly three-quarters of families face one of the standard marginal statutory tax rates, which are $0,15,28,31,36$, and 39.6 percent. Of the group that faces nonstandard marginal rates, the largest group faces rates between 16 and 27 percent. One notable finding is that the numbers of taxpayers paying the 39.6-percent and the 36-percent rate are very small, while there are much larger groups of taxpayers facing rates near these values that result from various phaseout provisions. These findings are similar to those in other recent studies of the distribution of marginal tax rates, such as Barthold, Koerner, and Navratil (1998) or U.S. Congress, Congressional Budget Office (2000). Lerman (1998) presents interesting evidence on the evolution of both payroll and income tax rates over time for families at particular income levels.

Table 8 reports the average marginal income tax rate, and payroll tax rate, for families in different adjusted AGI categories. The table shows that the average marginal payroll tax rate at low income levels is 15.3 percent, and that one must reach a family adjusted income of $\$ 50,000-$ 75,000 before the average payroll tax rate deviates noticeably from 15.3 percent. The table also shows that even in the very highest income

\section{TABLE 8}

Comparison of Marginal Personal Income Tax and Payroll Tax Rates for Families with Earned Income, 1999

\begin{tabular}{lcccc}
$\begin{array}{l}\text { 1999 family } \\
\text { adjusted AGI } \\
(\text { \$1000) }\end{array}$ & $\begin{array}{c}\text { Mean } \\
\text { personal } \\
\text { income tax } \\
\text { rate }(\%)\end{array}$ & $\begin{array}{c}\text { Mean } \\
\text { statutory } \\
\text { payroll tax } \\
\text { rate }(\%)\end{array}$ & $\begin{array}{c}\text { Percentage with } \\
\text { payroll tax MTR } \\
\text { > personal } \\
\text { income tax } \\
\text { MTR }\end{array}$ & $\begin{array}{c}\text { Percentage with } \\
\text { tax-benefit-linkage- } \\
\text { adjusted payroll } \\
\text { MTR > income tax } \\
\text { MTR }\end{array}$ \\
\hline$<10$ & -7.2 & 15.3 & 100.0 & 44.6 \\
$10-20$ & 12.7 & 15.3 & 75.1 & 16.2 \\
$20-30$ & 19.6 & 15.3 & 64.0 & 1.6 \\
$30-40$ & 17.4 & 15.3 & 71.8 & 3.1 \\
$40-50$ & 20.0 & 15.3 & 54.0 & 1.7 \\
$50-75$ & 22.1 & 15.2 & 38.7 & 0.5 \\
$75-100$ & 27.9 & 12.2 & 2.3 & 0.1 \\
$100-200$ & 30.2 & 9.8 & 0.1 & 0.1 \\
$200-500$ & 37.3 & 6.6 & 0.1 & 0 \\
$500-1000$ & 38.3 & 5.4 & 0.1 & 0 \\
$>1000$ & 37.8 & 5.2 & 0.1 & 0.1 \\
All & 17.2 & 14.4 & 54.2 & 9.2 \\
\hline
\end{tabular}

Notes: The tax-benefit-linkage-adjusted payroil tax rate is defined in the text. In computing payroll tax rates for each family, family members who have no earnings are not included in the calculation, so for married couples with a single earner, the payroll tax rate is the rate that applies to the spouse with
reported labor earnings. 
categories, the payroll tax rate still averages well above 2.9 percent, with a 5.2-percent rate, for example, for families with incomes of more than $\$ 1,000,000$. This arises because even in families with very high adjusted AGI, there are substantial numbers of earners who are earning less than the social security maximum for taxable earnings. We compute the payroll tax on a married couple as the equal-weighted average of the payroll tax rates on each of the spouses, which makes it possible for the couple's tax rate to be substantially higher than 2.9 percent even when most of the couple's wage income may be taxed at a payroll tax rate of 2.9 percent.

Table 8 also shows the average marginal personal income tax rate for families in different income ranges. For families with less than $\$ 10,000$ in annual income, the marginal tax rate is negative, reflecting the subsidy effects of the Earned Income Credit. For higher income categories, the average marginal tax rate is positive, and it exceeds 20 percent for families with incomes of more than $\$ 40,000$.

Table 8 reports the average marginal tax rate by income range, as well as the probability that families in different income ranges face marginal payroll tax rates that are greater than their income tax rates. For 54.2 percent of all families, the marginal payroll tax rate exceeds the marginal income tax rate. The probability of a higher marginal payroll tax rate is, not surprisingly, much greater at lower income levels.

\subsection{Tax-Benefit Linkage}

Our analysis of total tax burdens, and of marginal tax rates, has so far treated income and payroll taxes in the same fashion, even though there is a potentially important distinction between the two: social security benefit payments are linked to the payroll taxes that individuals pay during their working lives. There are no comparable income-related benefits that are tied to the amount that individuals pay in income taxes, or to the amount of hospital-insurance payroll tax. All persons over the age of 65 are eligible for the same Medicare benefits, regardless of their earnings.

Because both social security benefits and the associated payroll taxes are linked to earnings, the lifetime marginal burden of the OASI payroll tax may differ from the immediate marginal tax rate on earned income. Similarly, the total burden of the payroll tax may differ from the total tax payment that a family makes in a given year. This insight lies at the heart of studies of the lifetime progressivity of the social security system, such as Duggan, Gillingham, and Greenlees (1995), Coronado, Fullerton, and Glass (2000), and Gustman and Steinmeier (2000).

From a life-cycle perspective, the marginal burden of the social security payroll tax on an individual's current earnings is not the current 
marginal tax rate, but rather this marginal tax rate net of the marginal increase in the present value of future program benefits that flows from higher current earnings. Browning (1985), Burkhauser and Turner (1985), and others have made this point. Feldstein and Samwick (1992) compute net-of-benefits social security marginal payroll tax rates for earners in different income brackets and different family situations. Their calculations present tax rates on additional earnings for workers at different points in the income distribution, and their results show that these marginal tax rates can range from the statutory tax rate to substantial negative values (net subsidies) for workers in some circumstances. Their analysis recognizes differences in the linkage between social security benefits and earnings at different levels of earnings and for different family types, but it does not recognize income-related differences in mortality rates. Such mortality differences should ideally affect net-ofbenefits marginal tax rates.

Because most earners may anticipate non-trivial increases in their future benefits as a result of their current earnings, using life-cycle net-ofbenefits marginal payroll taxes rather than current statutory payroll tax burdens may affect our conclusions. To explore the sensitivity of our findings to allowing for future social security benefits, we use information on net-of-benefits social security marginal payroll tax rates calculated by Feldstein and Samwick (1992). We apply their estimates only to our marginal payroll tax rates for different families. We do not consider the broader question of the present value of total taxes net of total future changes in benefits, although our calculations suggest that this would be an important extension of the work presented here.

We translate Feldstein and Samwick's (1992) calculations for the social security system in force at the beginning of the 1990s to apply to the actual 1999 system of tax brackets and benefit amounts. In an unpublished appendix to their paper, Feldstein and Samwick (1992) present net-of-benefits payroll tax rates disaggregated by the marginal linkage between benefits and earnings for different workers. This linkage is determined by two variables: a worker's primary insurance amount (PIA) and average insured monthly earnings (AIME). The PIA and the AIME determine the marginal effect of additional earnings on future social security benefits. Feldstein and Samwick (1992) show net-ofbenefits payroll tax rates for workers of different ages (21-64 years old), facing various personal income tax brackets at the time of retirement $(0$, 15,28 , or 32 percent in 1990). They also consider two assumptions about retirement age (the social security normal retirement age and age 70 ), and they present separate results for men, men with dependent spouses, and women. Their analysis assumes that individuals use a 
2-percent real after-tax discount rate to compute the present discounted value of social security taxes net of benefits, and it ignores the share of OASDI payroll taxes that are collected in conjunction with the disability insurance program. Our illustrative calculations assume that the present discounted value of disability insurance benefits equals the disability insurance payroll tax, and we therefore exclude these payroll taxes from our calculations.

We assume that all workers retire at the normal retirement age and that they face a marginal personal income tax rate of 15 percent at retirement. We treat single workers and each member of two-worker married couples similarly, in that we assume that after retirement these workers will receive social security benefits that are based on their own wage history, rather than the wage history of their spouse. For each PIA/AIME class, we calculate a mean net social security payroll tax rate over all ages and both sexes. We do this separately for workers who expect to collect social security benefits on their own account, and for men who expect to collect benefits both for themselves and for their spouses. We then assign this tax rate to all earners within the class. For married joint filers with only a single wage earner, we assume that the wage earner is a man and apply the appropriate net-of-benefits marginal tax rate.

In 1999, the base year to which our calculations apply, the percentage of average indexed monthly earnings (AIME) applicable to PIA is 90 percent of the first $\$ 505$, plus 32 percent of the next $\$ 2,538$, plus $15 \%$ of any amount above $\$ 3,043$. Converting these monthly amounts to annual earnings results in three brackets for annual earnings: 0-\$6,060 (90percent bracket), $\$ 6,060-\$ 30,456$ (32-percent bracket), and over $\$ 30,456$ (15-percent bracket). For married couples with a single worker in these three brackets, the average net social security tax rates derived from Feldstein and Samwick (1992) are $-27.6,-2,6$, and 4.7 percent, respectively. For single persons and for earners who are part of two-earner couples, the respective tax rates are $-10.6,3.5$, and 7.6 percent. We assign workers to PIA/AIME classes based on their total annual earnings, defined as wages plus Schedule $C$ income.

Although our calculations assume that there are only six possible netof-benefits tax rates, and that none of these equals the statutory payroll tax rate, in practice there is much more heterogeneity. For most workers in practice, the net-of-benefits social security marginal tax rate is smaller than the statutory tax rate. In some cases, the net-of-benefits tax rate can be negative, implying that the social security system on balance subsidizes labor earnings. There are also some workers for whom the net-ofbenefits tax rate equals the statutory tax rate. These include low-earning 
married persons who are likely to collect social security benefits on the basis of their spouse's higher earnings rather than on their own earnings.

The last column of Table 8 illustrates how allowing for net-of-benefits social security payroll tax rates affects our earlier conclusions about the relative levels of the marginal income and payroll tax rates. While the fraction of families in the lowest income category (less than $\$ 10,000$ per year) for whom the marginal payroll tax rate exceeds the marginal income tax rate is still substantial (44.6 percent), for most other income groups this probability drops sharply. For all families, there is only a 9.2percent chance that the net-of-benefits payroll tax rate exceeds the marginal personal income tax rate. For families with adjusted AGI above $\$ 20,000$, the chance that the net-of-benefits payroll tax rate exceeds the income tax rate is very low. This very substantial change in part reflects the fact that small reductions in marginal payroll tax rates, beginning at a level of 15.3 percent, bring many families across a key threshold-the 15-percent income tax bracket. Small changes therefore change their payroll tax rate from greater than to less than their income tax rate.

The results in Table 8 suggest the importance of life-cycle considerations in evaluating the net burden of payroll taxes and income taxes. They suggest the potential value of combining the static tax analysis in models like TAXSIM with the dynamic record of household behavior in long-running panel data sets such as the Panel Survey of Income Dynamics.

\section{CONCLUSION}

This paper presents new evidence on the relative importance of income and payroll taxes for different types of families. The results suggest that when the employer and employee shares of the payroll tax are added together, payroll taxes exceed income taxes for roughly two thirds of families, and for virtually all tax-paying families at the bottom of the income distribution. There are substantial differences in the relative importance of the two taxes for families of different types, and in the extent to which the importance of income and payroll taxes has changed over time.

Since some payroll taxes are collected as part of programs that offer earnings-related benefits in the future, in particular social security retirement benefits, for some purposes it makes more sense to consider the present discounted value of payroll taxes net of benefits, rather than simply the current tax payments. Our exploratory estimates of such net tax rates suggest that on a present-discounted-value basis, roughly one- 
tenth of families face payroll tax rates that exceed their current personal income tax rates. Few of these families have adjusted AGI of greater than $\$ 20,000$.

The current calculations provide insight into the relative burdens of the income tax and the payroll tax systems over the past twenty years. They also suggest a number of topics that warrant further research. The expansion of the Earned Income Credit was clearly an important factor in changing the relative importance of income and payroll taxes for families at different points in the income distribution. It would be useful to identify other specific tax reforms that have affected that relationship. A second, and related, extension would involve documenting how demographic changes, in particular changes in the number of families relative to the U.S. population, have affected the distribution of payroll and income taxes.

Another valuable extension would involve more complete accounting of the net social security benefits associated with current labor earnings. A more complete tax-and-benefit accounting is likely to require data from a source such as the Panel Survey of Income Dynamics, or one of the multi-year merged files of tax returns. This is because complete analysis of the tax benefit linkage requires estimates of future social security benefits that are likely to flow to families in various current income categories. This, in turn, requires information on lifetime earnings profiles. Although a complex undertaking, this type of analysis would allow us to estimate the true net-of-benefits payroll tax in comparison with the personal income tax.

\section{REFERENCES}

Barthold, Thomas A., Thomas Koerner, and John F. Navratil (1998). "Effective Marginal Tax Rates Under the Federal Individual Income Tax: Death by One Thousand Pin Pricks?" National Tax Journal 51(September):553-564.

Browning, Edgar K. (1985). "The Marginal Social Security Tax on Labor." Public Finance Quarterly 13(July):227-252.

Burkhauser, Richard V., and John A. Turner (1985). "Is the Social Security Payroll Tax a Tax?" Public Finance Quarterly 13(July):253-268.

Coronado, Julia, Don Fullerton, and Thomas Glass (2000). "The Progressivity of Social Security." NBER Working Paper no. 7520.

Duggan, James E., Robert Gillingham, and John S. Greenlees (1995). "Progressive Returns to Social Security? An Answer from Social Security Records." U.S. Treasury Department, Office of the Assistant Secretary for Economic Policy. Research Paper 9501.

Ellwood, David, and Jeffrey Liebman (2001). "The Middle-Class Parent Penalty: Child Benefits in the U.S. Tax Code." (This volume.) 
Ettlinger, Michael P., and John F. O'Hare (1998). The Institute on Taxation and Economic Policy Tax Model. Washington: Citizens for Tax Justice.

Feenberg, Daniel R., and Elisabeth Coutts (1993). "An Introduction to the TAXSIM Model." Journal of Policy Analysis and Management 12(Winter):189-194. - Andrew W. Mitrusi, and James M. Poterba (1997). "Distributional Effects of Adopting a National Retail Sales Tax." In Tax Policy and the Economy, vol. 11, J. Poterba (ed.). Cambridge, MA: MTT Press.

Feldstein, Martin S. (1995). "The Effects of Marginal Tax Rates on Taxable Income: A Panel Study of the 1986 Tax Reform." Journal of Political Economy 103(June):551-571.

, and Andrew Samwick (1992). "Social Security Rules and Marginal Tax Rates." National Tax Journal 45(March):1-22.

Gruber, Jonathan, and Emmanuel Saez (2000). "The Elasticity of Taxable Income: Evidence and Implications." NBER Working Paper no. 7512.

Gustman, Alan, and Thomas Steinmeyer (2000). "How Effective Is Redistribution under the Social Security Benefit Formula?" Dartmouth College. Mimeo.

Lerman, Allen (1998). Average and Marginal Federal Income, Social Security, and Medicare, and Combined Tax Rates for Four-Person Families at the Same Relative Positions in the Income Distribution, 1955-1999. Washington: U.S. Treasury Department, Office of Tax Analysis.

Mitrusi, Andrew, and James Poterba (2000). "The Distribution of Payroll and Income Tax Burdens, 1979-1999." National Tax Journal 53:765-794.

U.S. Congress, Congressional Budget Office (1998). Estimates of Federal Tax Liabilities for Individuals and Families by Income Category and Family Type for 1995 and 1999. Washington: U.S. Congressional Budget Office.

(2000). An Economic Analysis of the Taxpayer Relief Act of 1997. Washington: U.S. Congressional Budget Office.

U.S. Congress, Joint Committee on Taxation (1993). Methodology and Issues in Measuring Changes in the Distribution of Tax Burdens. Washington: U.S. Government Printing Office. 
